\title{
LEMBAR KERJA SISWA UNTUK KEMAMPUAN PENALARAN MATEMATIS SISWA SMP KELAS VIII
}

\section{(STUDENT WORKSHEETS FOR THE MATHEMATICAL REASONING ABILITIES OF GRADE VIII JUNIOR HIGH SCHOOL STUDENTS)}

\author{
Aulia Mawar Yuwitaํ, Nyayu Masyita Ariani ${ }^{2}$ \\ 1Universitas Muhammadiyah Bengkulu, mawar.yuwita98@gmail.com \\ 2Universitas Muhammadiyah Bengkulu,nyayu.masyita@gmail.com
}

\begin{tabular}{l}
\hline \hline Info Artikel \\
\hline Received Aug 24, 2020 \\
Revised Aug 29, 2020 \\
Accepted Aug 31, 2020 \\
\\
Kata Kunci: \\
Penalaran Matematika, \\
Lembar kerja siswa, Auditory \\
Intellectually and Repetition
\end{tabular}

\section{Cara merujuk artikel} ini:

Yuwita, A.M. \& Nyanyu, M.A. (2020). Lembar Kerja Siswa Untuk kemampuan penalaran Matematis Siswa SMP kelas VIII. Vygotsky: Jurnal Pendidikan Matematika dan Matematika, 2 (2), pp. 126-135. Diunduh dari

http://jurnalpendidikan. unisla.ac.id/index.php/ VoJ/article/view/275/pdf

\begin{abstract}
This study aims to produce student worksheet for junior high shool students mathematical reasoning abilities with auditory intellectually and repetition learning model. The subject which is the focus of research is the VIII grade students of SMPN 20 Bengkulu city. 4-D model is used un the development of high worksheets. This research was conducted from 27 January-27 February. The resulting worksheets are valid based on the consideration of 3 validators and $Q$ Chochran test. $Q$ Chochran test showed that the calculated $Q$ results were smaller than significance lvel table $\propto=0,05(5 \%)$, which means that the validators agreed that students worksheet valid. The results obtained on the practicality test met the high practicality criteria with an overall average prakticality score of 3,53.
\end{abstract}

\begin{tabular}{l}
\hline \hline Abstrak \\
\hline Penelitian ini bertujuan menghasilkan Lembar Kerja \\
Siswa untuk kemampuan penalaran matematis siswa \\
SMP dengan model pembelajaran Auditory \\
Intellectually and Repetition. Subjek yang menjadi \\
fokus penelitian adalah siswa SMPN 20 Kota \\
Bengkulu kelas VIII. Digunakan model 4-D dalam \\
pengembangan LKS ini. Penelitian ini dilakukan pada \\
tanggal 27 Januari-27 Februari 2020. LKS yang \\
dihasilkan telah valid berdasarkan pertimbangan 3 \\
validator dan uji Q Chochran. Uji Q Chochran \\
menunjukkan hasil Q hitung lebih kecil dari tabel \\
taraf signifikasi $\propto=0,05$ ( $5 \%$, yang artinya ketiga \\
validator sepakat bahwa LKS valid. Hasil yang \\
didapatkan pada uji kepraktisan memenuhi kriteria \\
kepraktisan tinggi dengan skor keprakatisan rata-rata \\
secara keseluruhan adalah sebesar 3,53.
\end{tabular}

Copyright () 2020 Vygotsky: Jurnal Pendidikan Matematika dan Matematika. All right reserved 


\section{PENDAHULUAN}

Pembelajaran matematika adalah salah satu pembelajaran yang wajib diajarkan di bangku sekolah, mulai dari Sekolah Dasar (SD), Sekolah Menengah Pertama (SMP), Sekolah Menengah Atas (SMA), sampai perguruan tinggi. Matematika juga sering dipandang sebagai cara bernalar, karena matematika memuat cara pembuktian yang sahih dan valid, serta sifat penalaran matematika yang sistematis (Handayani, 2014). Sejalan dengan pendapat Khadijah \& Sukmawati (2013:70) bahwa "pengajaran matematika adalah suatu proses interaksi belajar mengajar oleh guru dan siswa dalam bidang studi matematika meliputi pola, bentuk, lambang, simbol, bahasa, operasi dan hubungan-hubungan yang tersusun sesuai dengan tahap perkembangan intelektual siswa pada suatu lingkungan belajar yang telah diatur dan direncanakan untuk mencapai tujuan pembelajaran matematika". Jadi, Pembelajaran matematika yaitu kegiatan belajar mengajar yang melibatkan guru dan siswa dalam bidang studi matematika untuk mencapai tujuan pembelajaran matemaika.

Permendikbud RI No.37 tahun 2018 menyatakan bahwa salah satu kompetensi yang harus dicapai siswa SMP kelas VIII dalam pembelajaran matematika adalah kompetensi keterampilan yakni mengolah, menyaji dan menalar dalam ranah konkret (menggunakan, mengurai, merangkai, memodifikasi dan membuat) dan ranah abstrak (menulis, membaca, menghitung, menggambar dan mengarang) sesuai dengan yang dipelajari di sekolah dan sumber lain yang sama dalam sudut pandang/teori. Menurut Permendikbud tersebut dapat diketahui bahwa salah satu kompetensi yang harus dicapai siswa SMP kelas VIII adalah kemampuan penalaran.

Penalaran dalam matematika memiliki peran yang sangat penting dalam proses berpikir seseorang. "Penalaran juga merupakan pondasi dalam pembelajaran matematika apabila kemampuan bernalar siswa tidak dikembangkan, maka bagi siswa matematika hanya akan menjadi materi yang mengikuti serangkaian prosedur dan meniru contoh-contoh tanpa mengetahui maknanya" (Fitri dkk, 2015:2). Menurut Peraturan Dirjen Dikdasmen Depdiknas Nomor 506/C/Kep/PP/2004 (dalam Fahrudi, 2019) tentang kriteria siswa memiliki kemampuan penalaran matematis adalah sebagai berikut:

a. Kemampuan menyajikan pernyataan matematika secara lisan, tertulis, gambar dan diagram

b. Kemampuan mengajukan dugaan

c. Kemampuan melakukan manipulasi matematika

d. Kemampuan menyusun bukti, memberikan alasan/ bukti terhadap kebenaran solusi

e. Kemampuan menarik kesimpulan dari pernyataan

f. Memeriksa kesahihan suatu argument

g. Menemukan pola atau sifat dar gejala matematis untuk membuat generalisasi 
Hasil wawancara yang dilakukan dengan salah satu guru mata pelajaran matematika di kelas VIII SMPN 20 Kota Bengkulu pada hari Kamis 14 November 2019, diperoleh informasi bahwa kemampuan penalaran matematis siswa masih rendah. Maka untuk menyelesaikan permasalahan tersebut perlu adanya tindakan berupa pengembangan salah satu produk berupa Lembar Kerja Siswa (LKS) yang valid untuk kemampuan penalaran matematis siswa. "LKS adalah bahan ajar cetak berupa lembaran kertas yang berisi materi, ringkasan, dan petunjuk- petunjuk pelaksanaan tugas pembelajaran yang harus dikerjakan oleh peserta didik, yang mengacu pada kompetensi dasar yang harus dicapai" (Prastowo, 2014:269). Sedangkan menurut Trianto (dalam Andriyani, 2016:72) "LKS merupakan panduan bagi siswa untuk melakukan kegiatan mendasar untuk memaksimalkan pemahaman sesuai indikator pencapaian hasil belajar. LKS berisi sekumpulan kegiatan yang memberikan kesempatan kepada siswa untuk memperluas pemahamannya terhadap materi yang dipelajari sesuai dengan tujuan pembelajaran yang ingin dicapai".

Berdasarkan uraian dan pendapat tersebut, dapat disimpulkan bahwa LKS merupakan salah satu bahan ajar berupa lembaran kertas yang berisi materi, ringkasan, dan petunjuk-petunjuk pelaksanaan tugas pembelajaran yang harus dikerjakan oleh siswa, bertujuan untuk meningkatkan kemampuan siswa dimana mengacu pada kompetensi dasar yang harus dicapai.

Alternatif model pembelajaran yang dapat digunakan untuk melatih kemampuan penalaran matematis siswa adalah model pembelajaran Auditory Intellectually and Repetition (AIR). Ubaidah (2017:12) menyatakan Model pembelajaran AIR merupakan salah satu model pembelajaran kooperatif dimana siswa belajar bersama dalam suatu kelompok tertentu pada proses pembelajaran yang menekankan pada 3 proses yaitu : Auditory (pendengaran) dalam aspek ini terjadi proses mendengarkan, menyimak, berbicara, presentasi, argumentasi, mengemukakan dan menanggapi pendapat. Intellectually (berpikir) yang berarti melakukan kemampuan berpikir yang perlu dilatih melalui latihan bernalar, memecahkan masalah, mengkontruksi dan menerapkan. Repetition (pengulangan) berupa pengerjaan soal, pemberian tugas atau kuis bertujuan untuk memperdalam dan memperluas pemahaman siswa.

Penelitian ini bertujuan mengembangkan LKS untuk kemampuan penalaran matematis siswa SMP melalui model AIR, dimana melihat tingkat validitas LKS. Manfaat penelitian ini diharapkan dapat memberikan kemudahan dalam pembelajaran matematika terutama melatih kemampuan penalaran matematis. Selain itu, juga memberikan manfaat bagi siswa, guru, sekolah dan peneliti sendiri.

\section{METODE PENELITIAN}

Jenis penelitian ini adalah penelitian pengembangan (Research and Development) yang produknya berupa LKS. Model pengembangan yang 
digunakan dalam pengembangan LKS ini adalah pengembangan Thiagarajan yang terkenal dengan istilah model 4-D. Model pengembangan 4-D ini terdiri dari empat tahapan yaitu tahap pendefinisian (define), tahap perencanaan (design), tahap pengembangan (develop), dan tahap penyebaran (disseminate). Namun pada penelitian ini tahap pengembangan hanya sampai pada tahap ketiga dengan tujuan menghasilkan LKS yang valid dan praktis. Prosedur pengembangan LKS pada penelitian ini dilakukan yaitu terlihat pada gambar berikut:

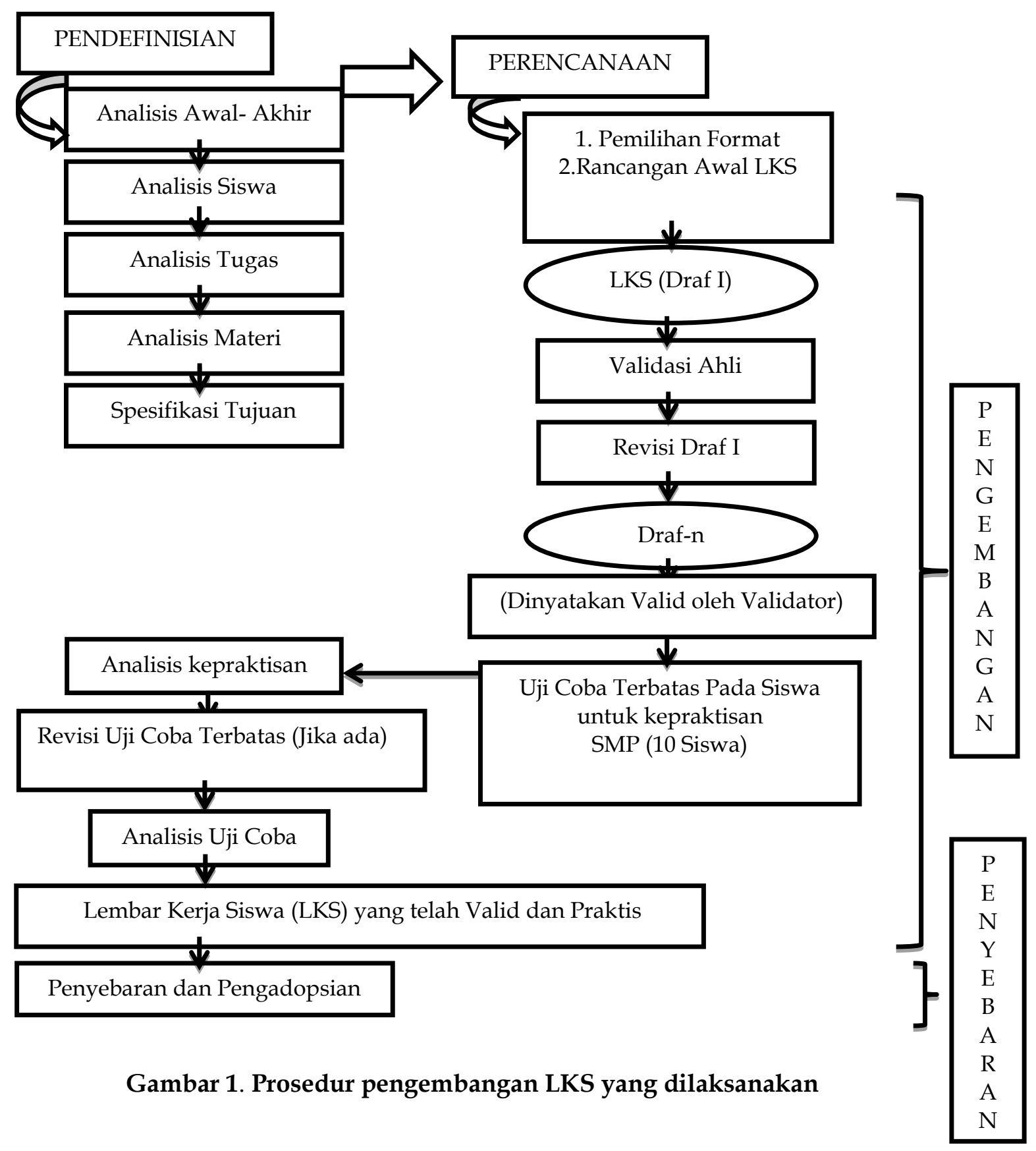

Tahap pendefinisian dilaksanakan untuk menetapkan dan mendefinisikan kebutuhan-kebutuhan pembelajaran dengan menganalisis tujuan dan batasan materi. Terdapat lima langkah pokok pada tahapan define, yaitu Analisis awal-akhir, analisisi siswa, analisisi konsep, analisis 
tugas, dan analisisi tujuan pembelajaran. Tahap kedua yaitu tahap perencanaan, tahap ini adalah tahap menyusun produk yang berupa draf awal LKS. Tahap perancangan produk ini terdiri dari dua kegiatan, yaitu pemilihan format (format selection), dan rancangan awal (initial design) LKS yang di dalamnya memfasilitasi kemampuan yang diharapkan. Tahap ketiga adalah tahap pengembangan, tahap pengembangan ini menghasilkan draf LKS valid untuk kemampuan penalaran matematis dan penggunaan model pembelajaran AIR yang telah direvisi berdasarkan masukan dari para ahli.

Analisis data pada penelitian ini berupa data kualitatif dan kuantitatif. Data kualitatif diperoleh dari saran/komentar yang dicantukan langsung pada LKS oleh validator. Adapun yang dianalisis adalah aspek muka dan isi. Aspek muka berupa kejelasan bahasa dan kejelasan gambar sedangkan pada aspek isi berupa konten dan kontruk.

Pada analisis data kuantitatif dilakukan melalui perhitungan $Q$ Cochran. Uji Q Cochran digunakan untuk mengetahui atribut apa saja yang dianggap sah (valid). Dalam metode ini validator diberikan pernyataan tertutup, yaitu pernyataan yang pilihan jawabannya terdiri dari Ya (1) dan Tidak (0) (Sugiyono, 2011). Hipotesis yang akan diuji yaitu $\mathrm{Ho}=$ semua validator seragam menyatakan LKS telah valid dan $\mathrm{Ha}=$ validator tidak seragam menyatakan bahwa LKS telah valid. Untuk mengetahui mana atribut yang valid, dilakukan uji Cochran dengan menentukan $Q$ hitung dengan rumus sebagai berikut:

$$
Q=\frac{(k-1)\left[k \sum_{j=1}^{k} G_{j}^{n}-\left(\sum_{j=1}^{k} G_{j}\right)^{2}\right]}{\left.\left.k \sum_{i=1}^{k} L_{i}-\sum_{i=1}^{N} L_{i}^{n}\right)\right)}
$$

(Sugiyono, 2011: 74)

Keterangan :

$\mathrm{Q}=$ hitung (Qhit)

$\mathrm{k}=$ jumlah validator

$G_{j}=$ jumlah yang sukses (jumah yang mendapat nilai 1 )

$L_{i}=$ jumlah yang sukses semua validator

$L_{i}^{2}=$ kuadrat dari $L_{i}$

Distribusi sampling $Q$ mendekati distribusi Chi kuadrat, oleh karena itu untuk menguji signifikasi harga $Q$ hitung tersebut, maka perlu dibandingkan dengan harga-harga kritis untuk Chi kuadrat. Derajat kebebasan yang digunakan untuk mencari $Q$ Chi kuadrat adalah $d k=k-1$, dengan $\alpha=0,05$ (5\%) kemudian cocokkan dengan nilai-nilai Chi Kuadrat sehingga didapat taraf signifikan dari tabel Chi Kuadrat. 
Keputusan yang diambil setelah menghitung $Q$ hasil hitung yaitu apabila $Q$ hasil menghitung lebih besar atau sama dengan tabel taraf signifikasi Chi Kuadrat $(\geq)$, maka Ho ditolak dan Ha diterima (Sugiyono,2011: 75). Berikut adalah tabel taraf signifikasi chi kuadrat:

Tabel 1. Taraf signifikasi Chi Kuadrat

\begin{tabular}{|c|c|c|c|c|c|c|}
\hline \multirow{2}{*}{$\mathrm{dK}$} & \multicolumn{6}{|c|}{ Taraf Signifikasi } \\
\hline & $50 \%$ & $30 \%$ & $20 \%$ & $10 \%$ & $5 \%$ & $1 \%$ \\
\hline 1 & 0,455 & 1,074 & 1,642 & 2,706 & 3,841 & 6,635 \\
\hline 2 & 0,139 & 2,408 & 3,219 & 3,605 & 5,991 & 9,210 \\
\hline 3 & 2,366 & 3,665 & 4,642 & 6,215 & 7,815 & 11,341 \\
\hline 4 & 3,357 & 4,878 & 5,989 & 7,779 & 9,488 & 13,277 \\
\hline
\end{tabular}

LKS yang dinyatakan telah valid berdasarkan pertimbangan 3 validator dan uji Q Chochran selanjutnya dilakukan uji coba terbatas kepada 10 siswa SMPN 20 Kota Bengkulu pada tanggal 27 Januari- 27 Februari 2020 untuk menentukan tingkat kepraktisan LKS. Untuk melakukan analisis kepraktisan, diperoleh berdasarkan data pada lembar angket kepraktisan yang diberikan kepada siswa. Hasil data yang diperoleh dari masing-masing angket dianalisis menggunakan teknik analisis rata-rata (diadaptasi dari Hobri dalam Hidayanti dan Utami, 2016:49). Data yang digunakan untuk menentukan tingkat kepraktisan LKS berupa data kuantitatif dengan empat sekala, yaitu :

- Skala 4 untuk pernyataan sangat setuju (SS)

- Skala 3 untuk pernyataan setuju (S)

- Skala 2 untuk pernyataan tidak setuju (TS)

- Skala 1 untuk pernyataan sangat tidak setuju (STS)

Rumus untuk mengetahui nilai rata-rata kepraktisan LKS berdasarkan analisis data tersebut yakni sebagai berikut:

$$
\mathrm{P}=\frac{\sum_{i=1}^{m} I_{i}}{m}
$$

(Sumber: Hobri dalam Hidayanti dan Utami, 2016:49)

Keterangan:

$P \quad=$ Tingkat kepraktisan LKS 
$I_{i}=$ Rata- rata indikator ke-i

$m=$ Banyaknya indikator

Selanjutnya nilai $P$ dirujuk pada kriteria penilaian hasil kepraktisan LKS seperti tabel berikut:

Tabel 2. Kriteria Penilaian Hasil Kepraktisan

\begin{tabular}{ccc}
\hline Interval & Kriteria Kepraktisan & Keterangan \\
\hline $1 \leq P<1,75$ & Sangat Rendah & Revisi Total \\
$1,75 \leq \mathrm{P}<2,5$ & Rendah & Revisi Sebagian \\
$2,5 \leq \mathrm{P}<3,25$ & Sedang & Revisi sebagian \\
$3,25 \leq \mathrm{P}<4$ & Tinggi & Tidak Perlu Revisi \\
$\mathrm{P}=4$ & Sangat Tinggi & Tidak Perlu Revisi \\
\hline & (Sumber: Hobri dalam Hidayanti dan Utami,2016:50)
\end{tabular}

\section{HASIL PENELITIAN DAN PEMBAHASAN}

Penelitian ini telah menghasilkan LKS untuk kemampuan penalaran matematis siswa SMP melalui model Auditory Intellectually and repetition. LKS ini terbagi menjadi 4 bagian, yaitu LKS pertama membahas konsep teorema Pythagoras, kedua tripel Pythagoras dan jenis-jenis segitiga, ketiga segitiga istimewa, dan keempat aplikasi teorema Pythagoras dalam kehidupan sehari-hari.

\section{Validitas LKS}

Untuk menghasilkan LKS yang valid dilakukan proses validitas oleh 3 validator. Berikut ditampilkan tabel proses validasi berdasarkan data kualitatif:

a) Draf I

Permasalahan yang divalidasi pada draf 1 berdasarkan komentar dan saran dari validator ke dua yaitu agar memperbaiki gambar. Satu gambar untuk satu permasalahan. Di bawah ini adalah permasalahan yang divalidasi pada draf I: 


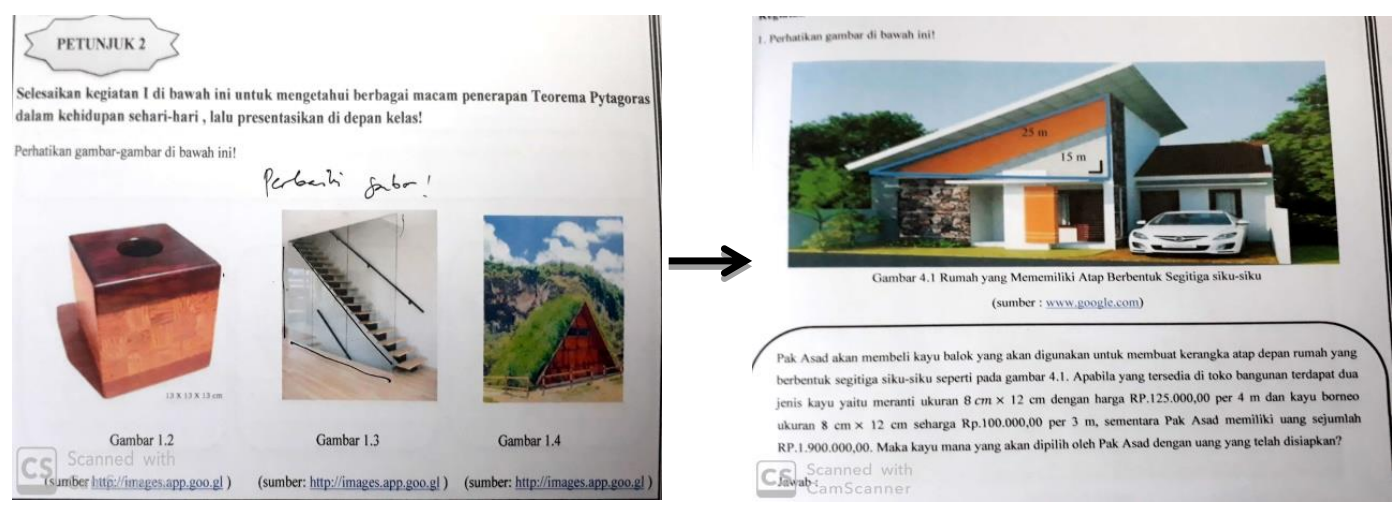

Gambar 2. Permasalahan yang Divalidasi pada Draf I

b) Draf II

Terdapat beberapa komentar dan saran dari validator pada draf II yaitu, validator kedua mengatakan bahwa gambar diganti dengan yang lebih sederhana. Sedangkan komentar dari validator ketiga yaitu gambar terlalu sulit bagi siswa. Permasalahan yang divalidasi pada draf II adalah sebagai berikut:

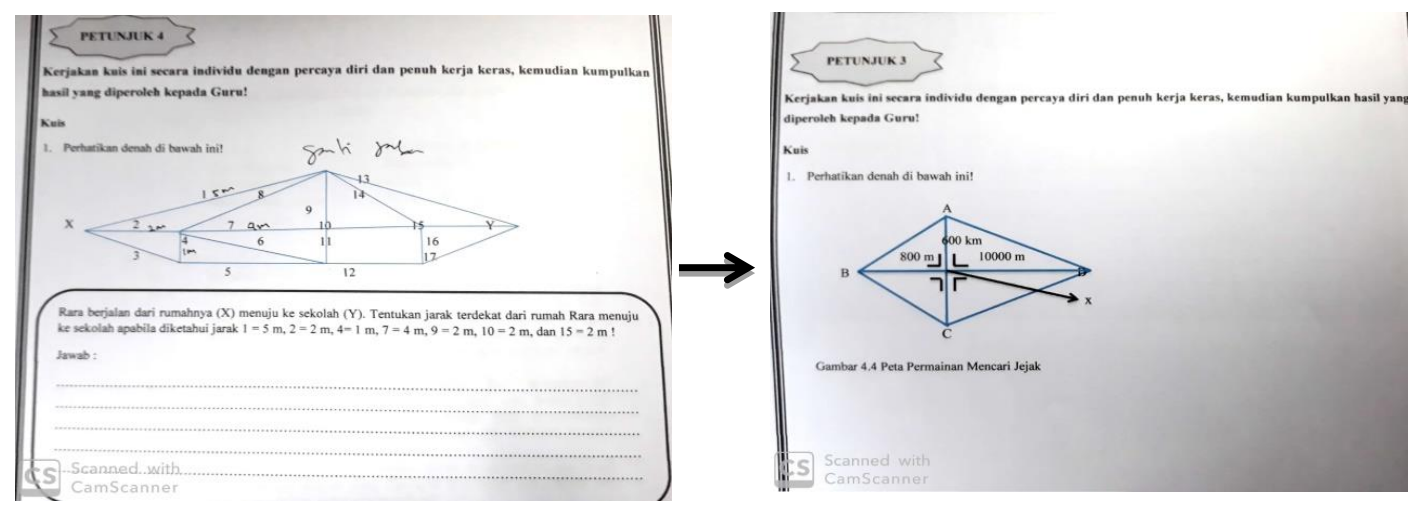

Gambar 3. Permasalahan yang Divalidasi pada Draf II

c) Draf III

Validator kedua memberikan komentar dan saran bahwa hilangkan kata "tentukanlah" pada permasalahan draf III karena agar melatih penalaran matematis siswa pada indikator kemampuan mengajukan dugaan. Berikut ini permasalahan yang divalidasi pada draf III :

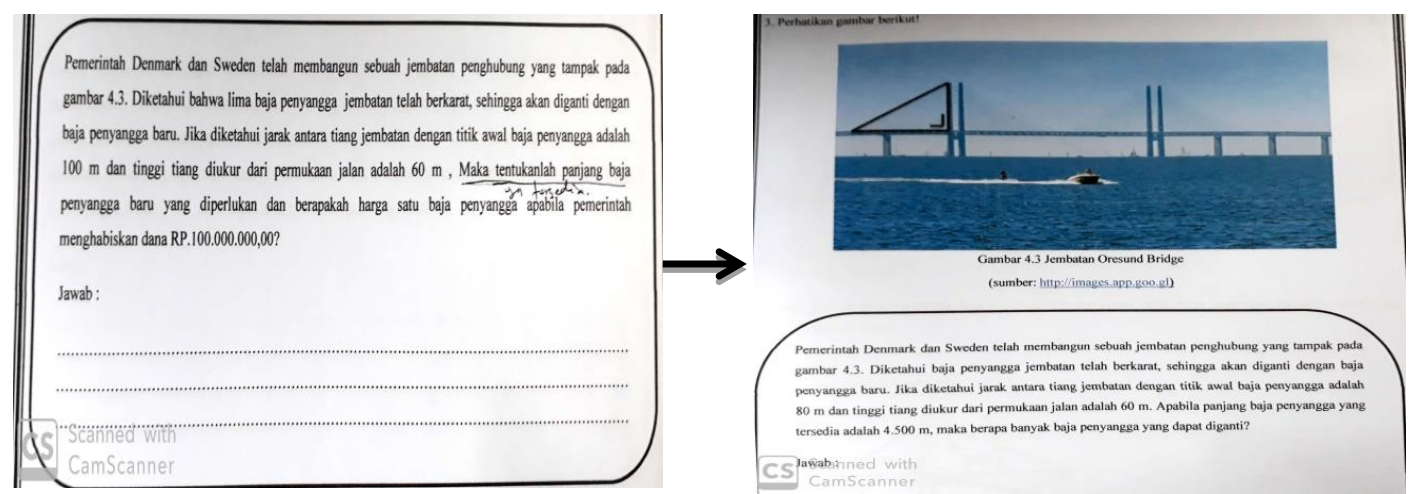

Gambar 4. Permasalahan yang Divalidasi pada Draf III 
Berdasarkan data kuantitatif dinyatakan bahwa LKS yang dikembangkan telah valid dilihat dari hasil $\mathrm{Q}$ hasil hitung yakni lebih kecil dari tabel taraf signifikasi Chi Kuadrat. Berikut adalah tebel data kualitatif validasi LKS menggunakan uji Q Cochran:

Tabel 3. Uji Validasi LKS menggunakan uji Q Cochran

\begin{tabular}{ccccc}
\hline LKS & $\begin{array}{c}\text { Nilai } \\
\text { Qhitung }\end{array}$ & $\begin{array}{c}\text { Nilai Chi } \\
\text { Kuadrat }(5 \%)\end{array}$ & Kesimpulan & Keterangan \\
\hline LKS 1 & 2,00 & 5,991 & Terima Ho & Seragam valid \\
LKS 2 & 3,00 & 5,991 & Terima Ho & Seragam valid \\
LKS 3 & 2,00 & 5,991 & Terima Ho & Seragam valid \\
LKS 4 & 0,667 & 5,991 & Terima Ho & Seragam valid \\
\hline
\end{tabular}

(Sugiyono, 2011)

\section{Kepraktisan LKS}

Tahap uji kepraktisan pada penelitian ini dilakukan dengan menghitung tingkat kepraktisan LKS. Berdasarkan respon siswa kriteria kepraktisan LKS berada pada kepraktisan tinggi, dimana nilai skor kepraktisan rata-rata secara keseluruhan siswa adalah sebesar 3,53.

\section{SIMPULAN DAN SARAN}

Berdasarkan penelitian pengembangan yang telah dilakukan diperoleh bahwa LKS untuk kemampuan penalaan matematis siswa SMP melalui model AIR yang dikembangkan telah valid dan praktis. Tingkat validitas LKS dapat dilihat dari hasil uji $Q$ Chochran dengan menunjukkan hasil $\mathrm{Q}$ hitung lebih kecil dari tabel taraf signifikasi $\propto=0,05(5 \%)$. Hasil yang didapatkan pada uji kepraktisan memenuhi kriteria kepraktisan tinggi dengan skor keprakatisan rata-rata secara keseluruhan adalah sebesar 3,53. Maka diharapkan pada penelitian selanjutnya dapat dilakukan uji coba secara luas.

\section{DAFTAR RUJUKAN}

Andriyani, R. 2016. Pengembangan Lembar Kerja Siswa (LKS) Kemampuan Komunikasi Matematis Pada Materi Segiempat Dan Segitiga Untuk SMP Kelas VII.

[Online].

Tersedia:http://r.search.yahoo.com/_ylt=Awrxgvlr5NddySgAbwb3 RQx.;_ylu=X3oDMTBycnYxMDN2BGNvbG8Dc2czBHBvcwM2BHZ0 aWQDBHNIYwNzcg-- [22 November 2019].

Handayani, I,M. 2014. Keefektifan Auditory Intellectually Repetition Berbantuan LKPD terhadap Kemampuan Penalaran Peserta Didik SMP. [online]. Tersedia:http://lib.unnes.ac.id/id/eprint/18854 [12 Oktober 2019].

Hidayanti, D \& Utami, T.H. 2016. Pengembangan Lembar Kegiatan Siswa (LKS) Matematika Dengan Pendekatan Saintifik Pada Pokok Bahasan Garis 


Singgung Lingkaran Untuk SMP Kelas VIII.

Tersedia:http:/ / ejurnal.citrabakti.ac.id/indeks.php/jipcb/article/vi ew/76 [12 Oktober 2019].

Fahrudi, F. E. 2019. Penalaran Matematis Siswa dalam Pemecahan Masalah Matematika Ditinjau Dari kemampuan Akademik Siswa.[Online]. Tersedia: http://repo-tulungagung.ac.id/10797/ [19 Februari 2020].

Fitri, N., Hundiono, B., \& Ahmad, D. 2015. Meningkatkan Kemampuan Penalaran Siswa Dengan Wawancara Klinis Pada Pemecahan Masalah Aritmatika Sosial Kelas VIII SMP. [Online]. Tersedia:http://media.neliti.com/media/publications/214655meningkatkan-kemampuan-penalaran-siswa-d.pdf $\quad[13$ November 2019].

Khadijah, S,.\& Sukmawati, R.A. 2013. Efektivitas Model Pembelajaran Auditory Intellectually Repetition Dalam Pengajaran Matematika Di Kesa VII MTS.

[Online]. Tersedia:http://ppjp.ulm.ac.id/jurnal/index.php/edumat/article/d ownload/568/485 [10 Oktober 2019].

Permendikbud. Nomor 37 Tahun 2018 Tentang Perubahan Atas Permendikbud Nomor 24 Tahun 2016 Tentang: Kompetensi Inti Dan Kompetensi Dasar Pembelajaran Pada Kurikulum 2013 Pada Pendidikan Dasar Dan Pendidikan Menengah. Jakarta: Permendikbud. [online]. Tersedia:http:/ / www.google.com/url?sa=t\&source=web\&rct=j\&url =http://www.infoguruku.net/2019/01/download-permendikbudno37-tahun2018.html\%3Fm\%3D1\&ved=2ahUKEwiW75_tq6flAhUy8HMBHSUx C7kQFjADegQIAxAB\&usg=ADvVaw3CEelJyGsc7MZMfIm316QS [05 Desember 2019].

Prastowo, A. 2014. Pengembangan Bahan Ajar Tematik Tinjauan Teoritis dan Praktik. Jakarta: Kencana Prenadamedia Grub

Rumus Hitung. 2013. Tabel Chi Kuadrat Dan Cara Penggunaannya. [online]. Tersedia:http:/ / rumushitung.com/2013/02/02tabel-chi-square-dancara-menggunakannya/ [7 Desember 2019].

Sugiyono. 2011. Statistik Nonparametris untuk Penelitian. Bandung: Alfabeta Ubaidah, N. 2017. Meningkatkan Kemampuan Penalaran Siswa Melalui Pembelajaran Auditory Intellectually Repetition Berbantuan Buku Siswa Pada Materi Persamaan Trigonometri. [Online]. Tersedia:http://jurnal.umj.ac.id/indeks.php/fbc/article/view/1725 [15 Oktober 2019]. 